\title{
Perbandingan Penggunaan SAW dan AHP untuk Penentuan Prioritas Maintenance Rusunawa Depok
}

\author{
Aditya Alif ${ }^{[1]}$, Ilham Rahmaditia Arlingga ${ }^{[2]}$, Ika Nur Suciati ${ }^{[3]}$, Bagus Priambodo ${ }^{[4]}$ \\ Program Studi Sistem Inforrmasi [1], [2], [3], [4] \\ Universitas Mercu Buana \\ Jakarta Barat, DKI Jakarta \\ 41816110010@student.mercubuana.ac.id ${ }^{[1]}, 41816110031 @$ student.mercubuana.ac.id ${ }^{[2]}$, \\ 41816110087@student.mercubuana.ac.id ${ }^{[3]}$,bagus.priambodo@mercubuana.ac.id ${ }^{[4]}$
}

\begin{abstract}
Low costing flats are subsidized by the local government, but until now, there are still many flats that do not have a good system to manage the facility. The obstacle faced by the current management is that there is no system that can give priority scale there is no system that can provide a fast and precise priority scale to determine facilities that need to be repaired immediately by the management based on the availability resource so fast which facilities need to be repaired as soon as possible. Such as determining the priority of repairs among damaged public toilets or repairing damaged garden chairs. In this study, we propose the Simple Additive Weighting (SAW) method to determine priority maintenance for facilities in low-cost flats. The results of calculations using SAW are evaluated by comparing the results of calculations using the Analytical Hierarchy Process (AHP). The experimental results show that the ranking results using the SAW method are better than the results of ranking using the AHP, furthermore using SAW is also more efficient because the complexity required in the calculation is simpler
\end{abstract} AHP

Keywords: Maintenance priority, Decision Support System, SAW,

Abstract - Rumah susun merupakan tempat tinggal yang di subsidi oleh pemerintah daerah, akan tetapi sampai saat ini masih banyak rumah rusun yang belum memiliki sistem pengelolaan perbaikan fasilitas yang baik. Kendala yang dihadapi oleh pengelola saat ini adalah tidak adanya sistem yang dapat memberikan skala prioritas yang cepat dan tepat untuk menentukan fasilitas yang perlu diperbaiki segera oleh pengelola berdasarakan ketersediaan sumber daya yang ada . Seperti menentukan prioritas perbaikan diantara toilet umum yang rusak atau memperbaiki kursi taman yang rusak. Dalam penelitian ini kami mengusulkan metode Simple Additive Weighting (SAW) untuk menentukan prioritas perbaikan bagi fasilitas di rusunawa. Hasil perhitungan menggunakan SAW dievaluasi dengan membandingkan hasil perhitungan menggunakan Analytical Hierarchy Process (AHP). Hasil eksperimen menunjukan bahwa hasil perangkingan menggunakan metode SAW lebih akurat dibandingkan dengan hasil perangkingan menggunakan AHP, selain itu menggunakan SAW juga lebih efisien karena kompleksitas perhitungan dalam pembuatan rangking lebih singkat.

Kata Kunci : Prioritas perbaikan, Sistem Pendukung Keputusan, $S A W, A H P$

\section{PENDAHULUAN}

Perumahan atau kebutuhan papan merupakan salah satu kebutuhan dasar manusia yang berperan strategis dalam peningkatan kualitas sumber daya manusia. Pemerintah daerah membuat rumah susun dengan harga murah bersubsidi dengan tujuan untuk meningkatkan mutu lingkungan kehidupan dalam rangka peningkatan dan pemerataan kesejahteraan rakyat bidang perumahan dan pemukiman.

Kendala yang dihadapi oleh pengelola saat ini adalah tidak adanya pengelolaan yang dapat memberikan skala prioritas terhadap fasilitas mana yang perlu diperbaiki sesegera mungkin. Seperti menentukan prioritas perbaikan diantara toilet umum yang rusak atau memperbaiki kursi taman yang rusak, sehingga diperlukan waktu yang cukup lama bagi pengelola untuk memproses perbaikan karena perlu memperhitungkan fasilitas rusun mana yang perlu diperbaiki segera berdasarkan dengan waktu, tenaga kerja , biaya dan material yang dimiliki oleh oleh pengelola.

Sebelumnya telah banyak penelitian serupa yang telah dilakukan dalam membuat perangkingan untuk mengambil keputusan, antara lain penelitian dalam membuat perangkingan kinerja terbaik [1]][2]][3]][4] yang membedakan penelitian satu dengan yang lain adalah : variable penentu yang berbeda dalam setiap penelitian, hasil perhitungan bobot variable, dan keperluan penelitian yang berbeda. Perangkingan dalam menentukan kualitas [5][6][7][8][9][10[11], yang membedakan penelitian satu dengan yang lain adalah : variable penentu yang berbeda dalam setiap penelitian, objek penelitian dan periode pengamatan, dan hasil penelitian yang berbeda. Perangkingan dalam penentuan strategi[12[13[14] yang membedakan dengan penelitian yang lain adalah : variable penentu yang berbeda dalam penelitian, objek penelitian dan periode pengamatan, dan hasil penelitian yang berbeda

Sistem pendukung keputusan (SPK) telah banyak diterapkan untuk sebagai landasan dalam pengambilan keputusan untuk suatu masalah tertentu[11]. Metode SAW dan AHP telah banyak digunakan dalam sistem pendukung keputusan di berbagai bidang[14]. Metode AHP dan SAW banyak digunakan untuk mengambil keputusan yang berbentuk ranking[3]. Sistem 
pengambilan keputusan terdapat beberapa metode untuk menentukan prioritas maintenance seperti Simple Additive Weighting (SAW) dan Analytical Hierarchy Process (AHP). Penyelesaian Sistem Pendukung Keputusan dapat dilakukan dengan banyak metode tergantung pada banyaknya kriteria[12]. Sistem Pendukung Keputusan dalam penentuan prioritas maintenance dibuat berdasarkan kriteria dan bobot yang telah ditentukan oleh pengelola. Dengan demikian, penelitian ini menggunakan metode SAW dimana metode SAW merupakan metode pembilangan terbobot yang hasil penjumlahannya diperoleh dari bobot nilai pada setiap kriteria yang telah ditentukan, sehingga hasil penelitiannya akan lebih tepat.

Langkah pertama dalam implementasi SAW adalah menentukan nilai bobot pada setiap atribut, dilanjutkan dengan proses perangkingan yang akan menyeleksi alternatif terbaik dari kriteria yang sudah ditentukan[7]. Hasil perankingan akan digunakan untuk menentukan fasilitas mana yang akan diberikan prioritas utama untuk dilakukan perbaikan. Metode SAW juga lebih efisien karena kompleksitas perhitungan relatif lebih singkat. Hasil perhitungan menggunakan SAW di evaluasi dengan bertanya kepada staff maintenance di rumah susun. Selanjutnya hasil perangkingan menggunakan SAW dibandingkan dengan hasil perangkingan menggunakan Analytical Hierarchy Process (AHP).

\section{METODE PENELITIAN}

\section{A. Metode SIMPLE ADDITIVE WEIGHTING (SAW)}

Metode Simple Additive Weighting (SAW) sering dikenal dengan istilah metode penjumlahan terbobot. Metode Simple Additive Weighting merupakan metode yang banyak digunakan dalam pengambilan keputusan yang memiliki banyak atribut[2]. Metode Simple Additive Weighting (SAW) dapat membantu dalam pengambilan keputusan suatu kasus, akan tetapi perhitungan dengan menggunakan metode Simple Additive Weighting (SAW) ini hanya yang menghasilkan nilai terbesar yang akan terpilih sebagai alternatif yang terbaik [15] . Konsep dasar metode SAW adalah mencari penjumlahan terbobot dari rating kinerja pada setiap alternatif dan pada semua atribut[5]. Perhitungan akan sesuai dengan metode ini apabila alternatif yang terpilih memenuhi kriteria yang telah ditentukan. Metode Simple Additive Weighting (SAW) ini lebih efisien karena waktu yang dibutuhkan dalam perhitungan lebih singkat. Metode Simple Additive Weighting (SAW) membutuhkan proses normalisasi matriks keputusan (X) ke suatu skala yang dapat diperbandingkan dengan semua rating alternatif yang ada. Diberikan persamaan sebagai berikut:

$$
\begin{aligned}
& \mathrm{r}_{\mathrm{ij}}
\end{aligned}
$$

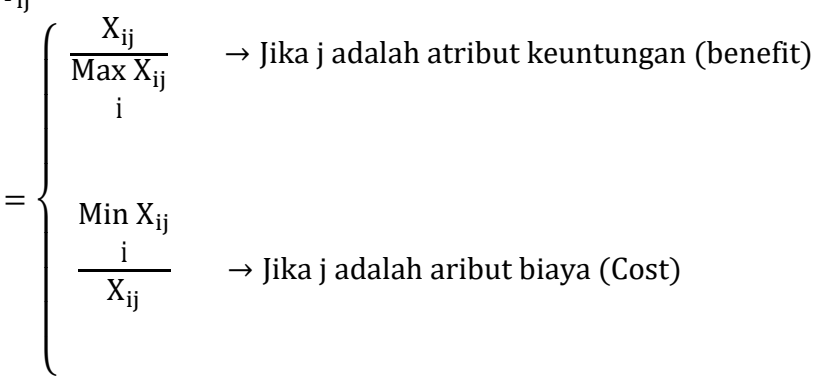

Dimana rij adalah rating kinerja ternormalisasi dari alternatif Ai pada atribut $\mathrm{Cj} ; \mathrm{i}=1,2, \ldots, \mathrm{m}$ dan $\mathrm{j}=1,2, \ldots, \mathrm{n}$. Nilai preferensi untuk setiap alternatif (Vi) diberikan sebagai berikut :

$$
\mathrm{V}_{i}=\sum_{j=1}^{n} w_{j} r_{i j}
$$

$\mathrm{Vi}=$ nilai prefensi

$\mathrm{wj}=$ bobot rangking

rij $=$ rating kinerja ternormalisasi

\section{B. Metode Analytical Hierarchy Process (AHP)}

Analytical Hierarchy Process (AHP) adalah metode untuk memecahkan suatu situasi yang komplek tidak terstruktur kedalam beberapa komponen dalam susunan yang hierarki. Analytical Hierarchy Process merupakan suatu metode pendukung keputusan yang dikembangkan oleh Thomas L. Saaty (Sean A.M.Pebakirang, Agung Sutrisno, Johan Neyland, 2017). Model pendukung keputusan ini akan menguraikan masalah multi faktor atau multi kriteria yang kompleks menjadi suatu hierarki[15]. Bagaimana peranan matriks dalam menentukan prioritas dan bagaimana menetapkan konsistensi. AHP banyak digunakan untuk mengekspresikan pengambilan suatu keputusan yang sangat efektif dari suatu permasalahan yang komplek[8].

Jika proses dekomposisi telah selesai dan heirarki telah tersusun dengan baik maka dapat dilakukan penilaian perbandingan berpasangan (pembobotan) pada tiap-tiap hierarki berdasarkan tingkat kepentingan relatifnya[10].

Hasil akhir dari penelitian ini adalah sebuah aplikasi berbasis web sistem pendukung keputusan yang dapat membantu admin untuk memilih fasilitas mana yang memiliki prioritas lebih untuk di maintenance, namun sebelumnya ditentukan daulu metode yang akan digunakan dalam studi kasus prioritas maintenance.

Metode pengumpulan data secara menyeluruh menggunakan 2 tahapan, diantaranya ialah wawancara dilakukan untuk mengetahui masalah yang timbul atau dialami langsung oleh yang bersangkutan[4].

Tahap pertama yang dilakukan peneliti adalah mewawancara narasumber untuk menentukan kriteria dan juga sub-krtiteria yang terlibat dalam pemilihan prioritas maintenance, 
selanjutnya melakukan perhitungan dan perankingan prioritas maintenance menggunakan metode SAW, lalu dilakukan perhitungan dan perankingan menggunakan metode AHP, dan tahap akhir adalah membandingkan kedua metode, kemudian ditentukan metode yang terbaik untuk studi kasus prioritas maintenance.

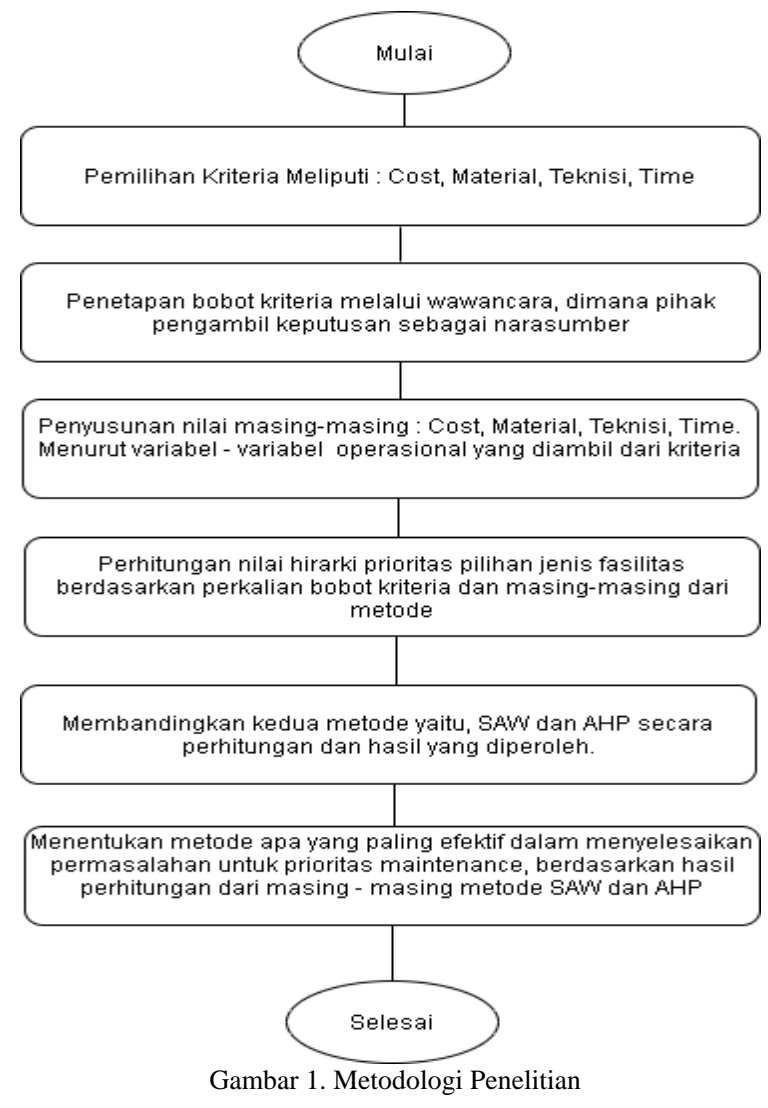

Tahap pertama yang dilakukan peneliti adalah mewawancara narasumber untuk menentukan kriteria dan juga sub-krtiteria yang terlibat dalam pemilihan prioritas maintenance.

Tahap kedua melakukan penetapan bobot kriteria melalui wawancara kepada narasumber.

Tahap ketiga melalukan penyusunan nilai masing-masing kriteria menurut variabel operasional yang diambil dari nilai bobot pada kriteria.

Tahap keempat melakukan perhitungan nilai prioritas fasilitas yang akan di perbaiki berdasarkan perkalian bobot kriteria dan menggunakan masing-masing metode pengambilan keputusan, yaitu : SAW dan AHP

Tahap kelima membandingkan kedua metode tersebut secara perhitungan dan hasil yang diperoleh, mana yang lebih cocok untuk pengambilan keputusan prioritas maintenance.

Tahap keenam menentukan metode mana yang lebih cocok untuk pengambilan keputusan prioritas maintenance berdasarkan hasil dan proses perhitungan dari masing-masing metode

\section{HASIL DAN PEMBAHASAN}

Kriteria - kriteria dalam pemilihan prioritas maintenance ini didapatkan dari wawancara dengan kepala rusun. Wawancara digunakan untuk mendapatkan informasi yang tepat dari narasumber yang terpercaya, wawancara dilakukan dengan cara penyampaian sejumlah pertanyaan dari pewawancara kepada narasumber.

Berikut ini hasil dari wawancara yang dilakukan peneliti dengan narasumber. Narasumber diminta untuk menjawab pertanyaan mengenai kriteria dan bobot untuk prioritas maintenance

\section{A. Hasil}

1) Perhitungan Menggunakan Metode Simple Additive Weighting (SAW)

Metode SAW digunakan untuk pencarian rangking alternatif, setelah didapatkan bobot prioritas untuk semua kriteria begitu juga faktor evaluasi untuk semua alternatif, Untuk melakukan pengambilan keputusan ini terdapat obyek yang akan dibahas atau goal kriteria dan alternatif[1]. Kemudian dilakukan normalisasi untuk masing-masing kriteria. Kriteria $\mathrm{C} 2$ dan $\mathrm{C} 4$ yang terlibat dalam perhitungan merupakan atribut kerugian (cost), kriteria $\mathrm{C} 1$ dan $\mathrm{C} 3$ yang terlibat dalam perhitungan merupakan atribut keuntungan (benefit). Karena semakin besar bobotnya, maka akan semakin menjadi prioritas. Skor akhir untuk sebuah alternative didapat dengan menjumlahkan seluruh hasil perkalian antara pemeliharaan dan bobot pada setiap atribut. Ranking pemeliharaan diharuskan telah melewati proses normalisasi [17].

Berdasarkan wawancara dengan pemilik rusun, nilai bobot diperoleh dengan biaya cost dan material yang disubsidi oleh pemerintah dan ketersediaan teknisi serta lama waktu pengerjaan yang diperlukan teknisi pada setiap jenis kerusakan. Setiap bobot mempunyai batasan nilai dengan rincian sebagai berikut

\section{Rincian Table bobot}

Langkah pertama adalah terlebih dahulu menentukan kriteria-kriteria, kriteria didapat dari narasumber yaitu kepala rusun. terlihat pada Table 1. Lalu kriteria tersebut akan ditentukan bobot penilaiannya, terlihat pada Table 2 berikut ini penilaiannya, terlihat pada Table 2 berikut ini:

\section{TABLE 1. KRITERIA PRIORITAS}

\begin{tabular}{|l|l|}
\hline Kriteria & Kode \\
\hline Cost & $\mathrm{C} 1$ \\
\hline Material & $\mathrm{C} 2$ \\
\hline Teknisi & $\mathrm{C} 3$ \\
\hline Time & $\mathrm{C} 4$ \\
\hline
\end{tabular}

TABLE 2. BOBOT KRITERIA PRIORITAS

\begin{tabular}{|l|c|}
\hline \multicolumn{2}{|c|}{ Bobot Utama } \\
\hline C 1 : cost & 35 \\
\hline C 2: material & 20 \\
\hline C 3 : teknisi & 15 \\
\hline C 4 : time & 30 \\
\hline
\end{tabular}


Setelah ditentukan kriteria dan bobot penilaiannya yang di dapatkan dari kepala rusun, selanjutnya adalah menentukan sub kriteria untuk masing-masing kriteriabeserta penilaiannya[9]. Berdasarkan wawancara dengan kepala rusun, nilai data crips diperoleh dengan cara membandingkan kebutuhan setiap kriteria.

Berikut Table data crips untuk masing-masing sub kriteria yang terlihat pada Table 3 untuk kriteria Cost, Table 4 untuk kriteria Material, Table 5 untuk kriteria Teknisi, dan Table 6 untuk kriteria Time.

TABLE 3. KRITERIA COST

\begin{tabular}{|c|c|c|c|}
\hline KODE & KRITERIA & CRIPS & NILAI \\
\hline $\mathrm{C} 1$ & COST & $0-1.000 .000$ & 35 \\
\hline $\mathrm{C} 1$ & COST & $1.000 .000-5.000 .000$ & 50 \\
\hline $\mathrm{C} 1$ & COST & $5.000 .000-10.000 .000$ & 70 \\
\hline
\end{tabular}

TABLE 4. KRITERIA MATERIAL

\begin{tabular}{|c|l|c|c|}
\hline KODE & KRITERIA & CRIPS & NILAI \\
\hline C2 & MATERIAL & $1-3$ & 25 \\
\hline C2 & MATERIAL & $4-10$ & 20 \\
\hline C2 & MATERIAL & $10-15$ & 10 \\
\hline
\end{tabular}

TABLE 5. KRITERIA TEKNISI

\begin{tabular}{|c|c|c|c|}
\hline KODE & KRITERIA & CRIPS & NILAI \\
\hline C3 & TEKNISI & $1-3$ & 20 \\
\hline C3 & TEKNISI & $4-6$ & 10 \\
\hline C 3 & TEKNISI & $7-10$ & 5 \\
\hline
\end{tabular}

TABLE 6. KRITERIA TIME

\begin{tabular}{|c|c|c|c|}
\hline KODE & KRITERIA & CRIPS & NILAI \\
\hline C4 & TIME & $1-3$ & 20 \\
\hline C4 & TIME & $4-9$ & 15 \\
\hline C4 & TIME & $11-30$ & 10 \\
\hline
\end{tabular}

Setelah ditentukan data crips dan nilai kriteria, selanjutnya adalah menentukan alternatif untuk masing-masing kriteria beserta penilaiannya. Berikut ini Table penilaian untuk masingmasing alternatif yang terlihat pada Table 7 untuk data alternatif, Table 8 untuk data nilai alternatif, dan Table 9 untuk bobot nilai.

TABLE 7. DATA ALTERNATIF

\begin{tabular}{|c|c|}
\hline \multicolumn{2}{|c|}{ DATA ALTERNATIF } \\
\hline KODE & NAMA ALTERNATIF \\
\hline A 1 & Pintu \\
\hline A 2 & Jendela \\
\hline A 3 & Atap \\
\hline A 4 & Kran \\
\hline A 5 & Lampu \\
\hline A 6 & Closet \\
\hline
\end{tabular}

TABLE 8. DATA NILAI ALTERNATIF

\begin{tabular}{|c|c|c|c|c|}
\hline \multicolumn{5}{|c|}{ DATA NILAI ALTERNATIF } \\
\hline KODE & C 1 & C 2 & C 3 & C 4 \\
\hline A 1 & 1.350 .000 & 2 & 1 & 1 \\
\hline A 2 & 2.500 .000 & 5 & 4 & 6 \\
\hline A 3 & 7.500 .000 & 12 & 7 & 11 \\
\hline A 4 & 300.000 & 4 & 7 & 2 \\
\hline A 5 & 150.000 & 2 & 2 & 2 \\
\hline A 6 & 5.000 .000 & 5 & 5 & 11 \\
\hline
\end{tabular}

TABLE 9. BOBOT NILAI ALTERNATIF

\begin{tabular}{|c|c|c|c|c|}
\hline BOBOT & C 1 & C 2 & C 3 & C 4 \\
\hline A 1 & 50 & 25 & 20 & 20 \\
\hline A 2 & 50 & 20 & 10 & 15 \\
\hline A 3 & 70 & 10 & 5 & 10 \\
\hline A 4 & 35 & 20 & 20 & 20 \\
\hline A 5 & 35 & 25 & 20 & 20 \\
\hline A 6 & 50 & 20 & 10 & 10 \\
\hline
\end{tabular}

Kemudian matriks pada table 9 dinormalisasi dengan penghitungan sesuai dengan kecocokan kriteria masing - masing data (benefit/cost). Sehingga terbentuk matrik ternormalisasi (R) seperti pada Table 10 .

$\begin{array}{llll}\text { C1 } & \text { C2 } & \text { C3 } & \text { C4 } \\ \text { A1 }=(50 / 70) & (10 / 25) & (20 / 20) & (10 / 20) \\ \text { A2 }=(50 / 70) & (10 / 20) & (10 / 20) & (10 / 15) \\ \text { A3 }=(70 / 70) & (10 / 10) & (5 / 20) & (10 / 10) \\ \text { A4 }=(35 / 70) & (10 / 20) & (20 / 20) & (10 / 20) \\ \text { A5 }=(35 / 70) & (10 / 25) & (20 / 20) & (10 / 20) \\ \text { A6 }=(50 / 70) & (10 / 20) & (10 / 20) & (10 / 10)\end{array}$

Keterangan

C 1 dan C 3 = Benefit

C 2 dan $\mathrm{C} 4=$ Cost

Benefit $=$ Jika nilai terbesar adalah terbaik $=$ NILAI BOBOT $/$ NILAI MAKSIMAL

Cost $=$ Jika nilai terkecil adalah terbaik $=$ NILAI MINIMAL /NILAI BOBOT

TABLE 10. NORMALISASI ALTERNATIF

\begin{tabular}{|c|c|c|c|c|}
\hline \multicolumn{5}{|c|}{ NORMALISASI } \\
\hline KODE & C 1 & C 2 & C 3 & C 4 \\
\hline A 1 & 0,714 & 0,4 & 1 & 0,5 \\
\hline A 2 & 0,714 & 0,5 & 0,5 & 0,666667 \\
\hline A 3 & 1 & 1 & 0,25 & 1 \\
\hline A 4 & 0,5 & 0,5 & 1 & 0,5 \\
\hline A 5 & 0,5 & 0,4 & 1 & 0,5 \\
\hline A 6 & 0,714 & 0,5 & 0,5 & 1 \\
\hline
\end{tabular}

Langkah selanjutnya adalah penghitungan hasil akhir perangkingan yang diperoleh dari penjumlahan dari perkalian hasil normalisasi pada Table 10 dengan bobot pada Table 2 yang bersesuaian elemen kolom matrik. Dengan perhitungan sebagai berikut:

$\mathrm{A} 1=(35 \mathrm{x} 0,714)+(20 \times 0,4)+(15 \mathrm{x} 1)+(30 \times 0,5)$

$\mathrm{A} 2=(35 \mathrm{x} 0,714)+(20 \times 0,5)+(15 \times 0,5)+(30 \times 0,666667)$

$\mathrm{A} 3=(35 \mathrm{x} 1)+(20 \times 1)+(15 \times 0,25)+(30 \times 1)$ 
$\mathrm{A} 4=(35 \mathrm{x} 0,5)+(20 \mathrm{x} 0,5)+(15 \mathrm{x} 1)+(30 \times 0,5)$

$\mathrm{A} 5=(35 \times 0,5)+(20 \times 0,4)+(15 \times 1)+(30 \times 0,5)$

$\mathrm{A} 6=(35 \mathrm{x} 0,714)+(20 \mathrm{x} 0,5)+(15 \times 0,5)+(30 \times 1)$

TABLE 11. HASIL PERANGKINGAN SAW

\begin{tabular}{|c|c|c|c|c|c|}
\hline $\mathbf{C ~ 1}$ & $\mathbf{C ~ 2}$ & $\mathbf{C ~ 3}$ & $\mathbf{C ~ 4}$ & TOTAL & RANKING \\
\hline 0,25 & 0,08 & 0,15 & 0,15 & 0,63 & 3 \\
\hline 0,25 & 0,1 & 0,075 & 0,2 & 0,625 & 4 \\
\hline 0,35 & 0,2 & 0,0375 & 0,3 & 0,8875 & 1 \\
\hline 0,175 & 0,1 & 0,15 & 0,15 & 0,575 & 5 \\
\hline 0,175 & 0,08 & 0,15 & 0,15 & 0,555 & 6 \\
\hline 0,25 & 0,1 & 0,075 & 0,3 & 0,725 & 2 \\
\hline
\end{tabular}

\section{B. Perhitungan Menggunakan Metode Analytical Hierarchy Process (AHP}

Untuk melakukan perhitungan menggunakan metode AHP, pertama yang harus dilakukan adalah menghitung faktor pembobotan hierarki untuk semua kriteria. Penghitungan dilakukan lewat cara menjumlahkan nilai setiap kolom yang bersangkutan untuk memperoleh normalisasi matriks, dan menjumlahkan nilai-nilai dari setiap baris dan membaginya dengan jumlah elemen untuk mendapatkan rata-rata[6.Jawaban narasumber dijadikan sebagai inputan untuk contoh perhitungan dimana narasumber memiliki preferensi untuk semua kriteria Maka matriks perbandingan hasil preferensi adalah:

TABLE 12. PEMBOBOTAN HIERARKI KRITERIA

\begin{tabular}{|l|c|c|c|c|}
\hline KRITERIA & Cost & Material & Teknisi & Time \\
\hline Cost & 1,00 & 5,00 & 7,00 & 3,00 \\
\hline Material & 0,20 & 1,00 & 3,00 & 0,14 \\
\hline Teknisi & 0,14 & 0,20 & 1,00 & 0,33 \\
\hline Time & 0,33 & 0,20 & 0,14 & 1,00 \\
\hline TOTAL & 1,68 & 6,40 & 11,14 & 4,48 \\
\hline
\end{tabular}

Setelah menentukan matriks pembobotan hierarki, langkah selanjutnya menjumlahkan tiap kolom kriteria dengan matriks total. Jumlah masing-masing baris pada Table 12 dapat dihitungdengan cara sebagai berikut:

Cost $\quad: 1 / 1.68=0.60,0.20 / 1.68=0.12,0.14 / 1.68=0.09$ $0.33 / 1.68=0.20$

Material : $5 / 6.40=0.78,1 / 6.40=0.16,0.20 / 6.40=0.03$ $0.20 / 6.40=0.03$

Teknisi $: 7 / 11.14=0.63,3 / 11.14=0.27,1 / 11.14=0.09$ $0.14 / 11.14=0.01$

Time $\quad: 3 / 4.48=0.67,0.14 / 4.48=0.03,0.33 / 4.48=0.07$ $1 / 4.48=0.22$

Setelah matriks normalisasikriteria didapatkan, langkah selanjutnya mencari nilai rata-rata tiap kolom kriteria yang telah dinormalisasi. Jumlah masing-masing baris pada Table 13 dapat dihitung dengan cara sebagai berikut:

Cost $:(0.60+0.12+0.09+0.20) / 4=0.67$

Material $:(0.78+0.16+0.03+0.03) / 4=0.14$

Teknisi : $(0.63+0.27+0.09+0.01) / 4=0.07$

Time $\quad(0.67+0.03+0.07+0.22) / 4=0.12$

Jumlah perhitungan diatas terlihat pada Table 13.

TABLE 13. KRITERIA YANG TELAH DINORMALISASI

\begin{tabular}{|l|r|r|r|r|r|}
\hline Kriteria & \multicolumn{1}{|c|}{ Cost } & \multicolumn{1}{|l|}{ Material } & \multicolumn{1}{l|}{ Teknisi } & Time & \multicolumn{1}{l|}{ Jumlah } \\
\hline Cost & 0,60 & 0,78 & 0,63 & 0,67 & 0,67 \\
\hline Material & 0,12 & 0,16 & 0,27 & 0,03 & 0,14 \\
\hline Teknisi & 0,09 & 0,03 & 0,09 & 0,07 & 0,07 \\
\hline Time & 0,20 & 0,03 & 0,01 & 0,22 & 0,12 \\
\hline Total & 1,00 & 1,00 & 1,00 & 1,00 & \\
\hline
\end{tabular}

Menjumlahkan nilai elemen setiap kolom dari nilai-nilai elemen matriks kriteria, maka hasil elemen setiap kolom terlihat pada Table 14, Table 15, Table 16 dan Table 17.

Contoh terlihat pada Table 14

$$
\begin{array}{ll}
\text { Pintu } & : 1+5+3+0,33+0,33+5=14,67 \\
\text { Atap } & : 0.20+1+0,33+0,14+0,11+0,14=1,93 \\
\text { Jendela } & : 0.33+3+1+0,33+0,20+5=9,87 \\
\text { Kran } & : 3+7+3+1+4+3=21 \\
\text { Lampu } & : 3+9+5+4+1+3=25 \\
\text { Closet } & : 0,20+7+0,20+0,33+0,33+1=9,07
\end{array}
$$

TABLE 14. PEMBOBOTAN HIERARKI UNTUK KRITERIA COST

\begin{tabular}{|l|r|r|r|r|r|r|}
\hline \multicolumn{1}{|c|}{ Cost } & \multicolumn{1}{c|}{ Pintu } & \multicolumn{1}{c|}{ Atap } & \multicolumn{1}{c|}{ Jendela } & \multicolumn{1}{c|}{ Kran } & Lampu & Closet \\
\hline Pintu & 1,00 & 0,20 & 0,33 & 3,00 & 3,00 & 0,20 \\
\hline Atap & 5,00 & 1,00 & 3,00 & 7,00 & 9,00 & 7,00 \\
\hline Jendela & 3,00 & 0,33 & 1,00 & 3,00 & 5,00 & 0,20 \\
\hline Kran & 0,33 & 0,14 & 0,33 & 1,00 & 4,00 & 0,33 \\
\hline Lampu & 0,33 & 0,11 & 0,20 & 4,00 & 1,00 & 0,33 \\
\hline Closet & 5,00 & 0,14 & 5,00 & 3,00 & 3,00 & 1,00 \\
\hline Total & 14,67 & 1,93 & 9,87 & 21,00 & 25,00 & 9,07 \\
\hline
\end{tabular}

TABLE 15. Pembobotan Hierarki untuk Kriteria Material

\begin{tabular}{|l|c|c|c|c|c|c|}
\hline Material & Pintu & $\begin{array}{c}\text { Ata } \\
\mathbf{p}\end{array}$ & Jendela & $\begin{array}{c}\text { Kra } \\
\mathbf{n}\end{array}$ & $\begin{array}{c}\text { Lamp } \\
\mathbf{u}\end{array}$ & Closet \\
\hline Pintu & 1,00 & 0,14 & 0,20 & 7,00 & 3,00 & 0,20 \\
\hline Atap & 7,00 & 1,00 & 5,00 & 9,00 & 9,00 & 7,00 \\
\hline Jendela & 5,00 & 0,20 & 1,00 & 7,00 & 3,00 & 0,20 \\
\hline Kran & 0,14 & 0,11 & 0,14 & 1,00 & 0,50 & 0,33 \\
\hline Lampu & 0,33 & 0,11 & 0,33 & 2,00 & 1,00 & 0,33 \\
\hline Closet & 5,00 & 0,14 & 5,00 & 3,00 & 3,00 & 1,00 \\
\hline Total & 18,48 & 1,71 & 11,68 & $\begin{array}{c}29,0 \\
0\end{array}$ & 19,50 & 9,07 \\
\hline
\end{tabular}


TABLE 16. PEMBOBOTAN HIERARKI UNTUK KRITERIA TEKNISI

\begin{tabular}{|l|c|c|c|c|c|c|}
\hline Teknisi & Pintu & Atap & Jendela & Kran & Lampu & Closet \\
\hline Pintu & 1,00 & 0,33 & 0,50 & 0,25 & 0,33 & 0,14 \\
\hline Atap & 3,00 & 1,00 & 3,00 & 7,00 & 9,00 & 9,00 \\
\hline Jendela & 2,00 & 0,33 & 1,00 & 0,33 & 0,14 & 0,14 \\
\hline Kran & 4,00 & 0,14 & 3,00 & 1,00 & 2,00 & 3,00 \\
\hline Lampu & 3,00 & 0,11 & 7,00 & 0,50 & 1,00 & 3,00 \\
\hline Closet & 7,00 & 0,11 & 7,00 & 0,33 & 0,33 & 1,00 \\
\hline Total & 20,00 & 2,03 & 21,50 & 9,42 & 12,81 & 16,29 \\
\hline
\end{tabular}

TABLE 17. PEMBOBOTAN HIERARKI UNTUK KRITERIA TIME

\begin{tabular}{|l|c|c|c|c|c|c|}
\hline Time & Pintu & Atap & Jendela & Kran & Lampu & Closet \\
\hline Pintu & 1,00 & 0,20 & 0,33 & 5,00 & 5,00 & 0,20 \\
\hline Atap & 5,00 & 1,00 & 3,00 & 9,00 & 9,00 & 7,00 \\
\hline Jendela & 3,00 & 0,33 & 1,00 & 4,00 & 5,00 & 0,20 \\
\hline Kran & 0,20 & 0,11 & 0,20 & 1,00 & 2,00 & 3,00 \\
\hline Lampu & 0,20 & 0,11 & 0,20 & 0,50 & 1,00 & 0,20 \\
\hline Closet & 5,00 & 0,14 & 5,00 & 0,33 & 5,00 & 1,00 \\
\hline Total & 14,40 & 1,90 & 9,73 & 19,83 & 27,00 & 11,60 \\
\hline
\end{tabular}

Setelah menjumlahkan nilai elemen setiap kolom dari nilainilai elemen matriks kriteria, langkah selanjutnya menormalisasi nilai-nilai elemen matriks kriteria pada Table 14, Table 15, Table 16 dan Table 17 dapat dihitung dengan cara sebagai berikut

Contoh terlihat pada Table 14:

Pintu : (1.00/14.67), (0.20/1.93), $(0.33 / 9.87$ (3.00/21.00), (3.00/25,00), (0.20/9.07

Atap : (5,00/14.67), (1,00/1.93), (3,00/9.87 $(7,00 / 21.00),(9,00 / 25,00),(7,00 / 9.07$

Jendela : $(3,00 / 14.67),(0,33 / 1.93),(1,00 / 9.87$ $(3,00 / 21.00),(5,00 / 25,00),(0,20 / 9.07$

Kran : $(0,33 / 14.67),(0,14 / 1.93),(0,33 / 9.87$ $(1,00 / 21.00),(4,00 / 25,00),(0,33 / 9.07$

Lampu : $(0,33 / 14.67),(0,11 / 1.93),(0,20 / 9.87$ $(4,00 / 21.00),(1,00 / 25,00),(0,33 / 9.07$

Closet

$$
\text { : }(5,00 / 14.67),(0,14 / 1.93),(5,00 / 9.87
$$$$
(3,00 / 21.00),(3,00 / 25,00),(1,00 / 9.07
$$

Jumlah perhitungan diatas terlihat pada Table 18 .

TABLE 18. HIERARKI UNTUK KRITERIA COST YANG TELAH DINORMALISASI

\begin{tabular}{|l|c|c|c|c|c|c|c|}
\hline Elemen & Pintu & Atap & Jendela & Kran & Lampu & Closet & Jumlah \\
\hline Pintu & 0,07 & 0,10 & 0,03 & 0,14 & 0,12 & 0,02 & 0,08 \\
\hline Atap & 0,34 & 0,52 & 0,30 & 0,33 & 0,36 & 0,77 & 0,44 \\
\hline Jendela & 0,20 & 0,17 & 0,10 & 0,14 & 0,20 & 0,02 & 0,14 \\
\hline Kran & 0,02 & 0,07 & 0,03 & 0,05 & 0,16 & 0,04 & 0,06 \\
\hline Lampu & 0,02 & 0,06 & 0,02 & 0,19 & 0,04 & 0,04 & 0,06 \\
\hline Closet & 0,34 & 0,07 & 0,51 & 0,14 & 0,12 & 0,11 & 0,22 \\
\hline Total & 1,00 & 1,00 & 1,00 & 1,00 & 1,00 & 1,00 & \\
\hline
\end{tabular}

TABLE 19. HIERARKI UNTUK KRITERIA MATERIAL YANG TELAH DINORMALISASI

\begin{tabular}{|c|c|c|c|c|c|c|c|}
\hline $\begin{array}{c}\text { Eleme } \\
\mathbf{n}\end{array}$ & $\begin{array}{c}\text { Pint } \\
\mathrm{u}\end{array}$ & $\begin{array}{c}\text { Ata } \\
\mathrm{p}\end{array}$ & Jendela & $\begin{array}{c}\text { Kra } \\
\mathrm{n}\end{array}$ & $\begin{array}{c}\text { Lamp } \\
\mathrm{u}\end{array}$ & $\begin{array}{c}\text { Closet } \\
\text { Jumla } \\
\mathrm{h}\end{array}$ \\
\hline Pintu & 0,05 & 0,08 & 0,02 & 0,24 & 0,15 & 0,02 & 0,10 \\
\hline Atap & 0,38 & 0,59 & 0,43 & 0,31 & 0,46 & 0,77 & 0,49 \\
\hline
\end{tabular}

\begin{tabular}{|l|c|c|c|c|c|c|c|}
\hline $\begin{array}{c}\text { Eleme } \\
\mathbf{n}\end{array}$ & $\begin{array}{c}\text { Pint } \\
\mathrm{u}\end{array}$ & $\begin{array}{c}\text { Ata } \\
\mathrm{p}\end{array}$ & $\begin{array}{c}\text { Jendela } \\
\text { Kra } \\
\mathrm{n}\end{array}$ & $\begin{array}{c}\text { Lamp } \\
\mathrm{u}\end{array}$ & Closet & $\begin{array}{c}\text { Jumla } \\
\mathrm{h}\end{array}$ \\
\hline Jendela & 0,27 & 0,12 & 0,09 & 0,24 & 0,15 & 0,02 & 0,15 \\
\hline Kran & 0,01 & 0,07 & 0,01 & 0,03 & 0,03 & 0,04 & 0,03 \\
\hline Lampu & 0,02 & 0,07 & 0,03 & 0,07 & 0,05 & 0,04 & 0,04 \\
\hline Closet & 0,27 & 0,08 & 0,43 & 0,10 & 0,15 & 0,11 & 0,19 \\
\hline Total & 1,00 & 1,00 & 1,00 & 1,00 & 1,00 & 1,00 & \\
\hline
\end{tabular}

TABLE 20. HIERARKI UNTUK KRITERIA TEKNISI YANG TELAH DINORMALISASI

\begin{tabular}{|c|c|c|c|c|c|c|c|}
\hline $\begin{array}{c}\text { Eleme } \\
n\end{array}$ & $\begin{array}{c}\text { Pint } \\
\mathrm{u}\end{array}$ & $\begin{array}{c}\text { Ata } \\
\mathrm{p}\end{array}$ & Jendela & $\begin{array}{c}\mathrm{Kra} \\
\mathrm{n}\end{array}$ & $\begin{array}{c}\text { Lamp } \\
\mathrm{u}\end{array}$ & Closet & $\begin{array}{c}\text { Jumla } \\
\mathrm{h}\end{array}$ \\
\hline Pintu & 0,05 & 0,16 & 0,02 & 0,03 & 0,03 & 0,01 & 0,05 \\
\hline Atap & 0,15 & 0,49 & 0,14 & 0,74 & 0,70 & 0,55 & 0,46 \\
\hline Jendela & 0,10 & 0,16 & 0,05 & 0,04 & 0,01 & 0,01 & 0,06 \\
\hline Kran & 0,20 & 0,07 & 0,14 & 0,11 & 0,16 & 0,18 & 0,14 \\
\hline Lampu & 0,15 & 0,05 & 0,33 & 0,05 & 0,08 & 0,18 & 0,14 \\
\hline Closet & 0,35 & 0,05 & 0,33 & 0,04 & 0,03 & 0,06 & 0,14 \\
\hline Total & 1,00 & 1,00 & 1,00 & 1,00 & 1,00 & 1,00 & \\
\hline
\end{tabular}

TABLE 21. HIERARKI UNTUK KRITERIA TIME YANG TELAH DINORMALISASI

\begin{tabular}{|l|c|c|c|c|c|c|c|}
\hline $\begin{array}{c}\text { Eleme } \\
\mathbf{n}\end{array}$ & $\begin{array}{c}\text { Pint } \\
\mathrm{u}\end{array}$ & $\begin{array}{c}\text { Ata } \\
\mathrm{p}\end{array}$ & Jendela & $\begin{array}{c}\text { Kra } \\
\mathrm{n}\end{array}$ & $\begin{array}{c}\text { Lamp } \\
\mathrm{u}\end{array}$ & Closet & $\begin{array}{c}\text { Jumla } \\
\mathrm{h}\end{array}$ \\
\hline Pintu & 0,07 & 0,11 & 0,03 & 0,25 & 0,19 & 0,02 & 0,11 \\
\hline Atap & 0,35 & 0,53 & 0,31 & 0,45 & 0,33 & 0,60 & 0,43 \\
\hline Jendela & 0,21 & 0,18 & 0,10 & 0,20 & 0,19 & 0,02 & 0,15 \\
\hline Kran & 0,01 & 0,06 & 0,02 & 0,05 & 0,07 & 0,26 & 0,08 \\
\hline Lampu & 0,01 & 0,06 & 0,02 & 0,03 & 0,04 & 0,02 & 0,03 \\
\hline Closet & 0,35 & 0,08 & 0,51 & 0,02 & 0,19 & 0,09 & 0,20 \\
\hline Total & 1,00 & 1,00 & 1,00 & 1,00 & 1,00 & 1,00 & \\
\hline
\end{tabular}

Setelah menormalisasi nilai-nilai elemen matriks kriteria, langkah selanjutnya menghitung nilai prioritas kriteria, dengan cara menghitung nilai hierarki alternatif/kriteria dikali dengan jumlah nilai hierarki yang telah dinormalisasi, dapat dihitung dengan cara sebagai berikut

Contoh perhitungan pada Table 23, mengambil nilai hierarki kriteria pada table 12, lalu dikalikan dengan jumlah nilai hierarki yang telah dinormalisasi pada Table 13:

Cost

Material $\quad:(0.20 \times 0,67)+(1.00 \times 0.14)+(3.00 \times 0.07)+$ $(0.14 \times 0.12$

Teknisi $\quad:(0.14 \times 0,67)+0.20 \times 0.14)+(1.00 \times 0.07)+$ $(0.33 \times 0.12$

Time $:(0.14 \times 0,67)+0.20 \times 0.14)+(1.00 \times 0.07)+$ $(0.33 \times 0.12$

Maka hasil nilai prioritas kriteria terdapat pada Table 23: 
TABLE 22. NILAI PRIORITAS ALTERNATIF

\begin{tabular}{|l|r|c|r|r|}
\hline \multicolumn{1}{|c|}{ Elemen } & \multicolumn{1}{c|}{ Cost } & Material & \multicolumn{1}{c|}{ Teknisi } & Time \\
\hline Pintu & 0,630744 & 0,579863086 & 0,337705 & 0,827098 \\
\hline Atap & 3,768314 & 3,916775166 & 4,342888 & 3,828384 \\
\hline Jendela & 1,068978 & 1,108036398 & 0,403022 & 1,125087 \\
\hline Kran & 0,516316 & 0,205808977 & 1,299413 & 0,848471 \\
\hline Lampu & 0,487216 & 0,304954585 & 1,26655 & 0,208683 \\
\hline Closet & 1,761418 & 1,705903351 & 1,063544 & 1,730758 \\
\hline
\end{tabular}

\section{TABLE 23. NILAI PRIORITAS KRITERIA}

\begin{tabular}{|l|l|}
\hline Cost & 2,230916468 \\
\hline Material & 0,505163055 \\
\hline Teknisi & 0,233450134 \\
\hline Time & 0,378466466 \\
\hline
\end{tabular}

Langkah selanjutnya mencari rangking setiap alternative. Untuk mendapatkan rangkingmasing-masing bobot untuk alternative pilihan dikalikan dengan bobot dari kriteria dalam bentuk perkalian matrik sebagai berikut:

Pintu

$(0.630744 \times 2.230916468)+(0.579863086 \times 0.505163055)+$

$(0.337705 \times 0.233450134)+(0.827098 \times 0.378466466$

Jendela

$(3,768314 \times 2.230916468)+(3,916775166 \times 0.505163055)+$

$(4,342888 \times 0.233450134)+(3,828384 \times 0.378466466$

Atap

$(1,068978 \times 2.230916468)+(1,108036398 \times 0.505163055)+$

$(0,403022 \times 0.233450134)+(1,125087 \times 0.378466466$

Kran

$(0,516316 \times 2.230916468)+(0,205808977 \times 0.505163055)+$

$(1,299413 \times 0.233450134)+(0,848471 \times 0.378466466$

Lampu

$(0,487216 \times 2.230916468)+(0,304954585 \times 0.505163055)+$

$(1,26655 \times 0.233450134)+(0,208683 \times 0.378466466$

Closet

$(1,761418 \times 2.230916468)+(1,705903351 \times 0.505163055)+$

$(1,063544 \times 0.233450134)+(1,730758 \times 0.378466466$

TABLE 24. HASIL PERANGKINGAN AHP

\begin{tabular}{|l|c|c|}
\hline Nama Fasilitas Alternatif & AHP Value & AHP Rank \\
\hline PINTU & 2,091928 & 4 \\
\hline JENDELA & 12,848166 & 1 \\
\hline ATAP & 3,4644339 & 3 \\
\hline KRAN & 1,8802916 & 5 \\
\hline LAMPU & 1,6156465 & 6 \\
\hline CLOSET & 5,6946548 & 2 \\
\hline
\end{tabular}

\section{B. Pembahasan}

Berdasarkan Table 27 ada sedikit perbedaan dalam urutan peringkat alternatif. Perbedaannya terletak pada urutan peringkat 1,3,4 dari masing-masing metode. Dari penelitian perbedaan urutan peringkat alternative dipengaruhi oleh beberapa faktor

- Nilai peringkat alternative prioritas maintenance

- Faktor kriteria pembobotan

- Faktor perhitungan masing-masing metode.

Metode SAW menggunakan bobot tetap dan data crip sedangkan AHP menggunakan hierarki perbandingan antara karakter perhitungan bobot. Metode SAW memiliki variable cost dan benefit sehingga lebih cocok untuk menghitung prioritas maintenance.

TABLE 25. PERBANDINGAN PERHITUNGAN SAW DAN AHP

\begin{tabular}{|l|l|c|c|c|}
\hline $\begin{array}{c}\text { Nama } \\
\text { Fasilitas } \\
\text { Alternatif }\end{array}$ & $\begin{array}{c}\text { Nilai } \\
\text { SAW }\end{array}$ & $\begin{array}{c}\text { Rangking } \\
\text { SAW }\end{array}$ & $\begin{array}{c}\text { Nilai } \\
\text { AHP }\end{array}$ & $\begin{array}{c}\text { Rangking } \\
\text { AHP }\end{array}$ \\
\hline PINTU & 0,63 & 3 & 2,091928 & 4 \\
\hline JENDELA & 0,625 & 4 & 12,848166 & 1 \\
\hline ATAP & 0,8875 & 1 & 3,4644339 & 3 \\
\hline KRAN & 0,575 & 5 & 1,8802916 & 5 \\
\hline LAMPU & 0,555 & 6 & 1,6156465 & 6 \\
\hline CLOSET & 0,725 & 2 & 5,6946548 & 2 \\
\hline
\end{tabular}

Berdasarkan hasil observasi dan analisa dengan staff maintenance di rumah susun serta berdasarkan Pedoman Pemeliharaan dan Perawatan Bangunan Gedungyang dikeluarkan oleh Direktorat Jenderal Cipta Karya (2008) [18] terkait tingkat kerusakan bangunan gedung, kami menganalisa hasil perangkingan antara SAW dan AHP dalam menentukan prioritas maintenance adalah sebagai berikut :

- Hasil perangkingan no 1 menggunakan metode SAW lebih baik karena perbaikan atap yang bocor lebih utama (rangking no 1 SAW) daripada jendela yang rusak ( rangking no $1 \mathrm{AHP}$ ).

- Skala prioritas ditentukan melalui perhitungan dengan menggunakan metode SAW

- Ranking dalam hasil akhir dari perhitungan SAW menunjukan prioritas maintenance yang paling didahulukan mulai dari ranking 1 dan seterusnya.

- Hasil perangkingan no 3 menggunakan metode SAW lebih baik daripada AHP karena perbaikan pintu yang rusak lebih utama rangking no 3 SAW daripada jendela yang rusak (rangking no 3 AHP). Sedangkan berdasarkan hasil SAW atap merupakan prioritas no 1 atau lebih utama daripada pintu (no 3).

- Adapun hasil perangkingan no 4 menggunakan metode SAW adalah jendela sedangkan perangkingan menggunakan AHP adalah pintu ( rangking no 4 SAW).Betul seharusnya pintu lebih utama daripada jendela akan tetapi berdasarkan hasil SAW pintu merupakan prioritas no 3 ataulebih utama daripada jendela (no 4). 


\section{KESIMPULAN}

Pada pekerjaan perbaikan atap terjadi karena adanya kerusakan yang cukup parah pada bagian penutup atap diselasar rumah susun. Sehingga menjadi prioritas utama untuk segera dilakukan perbaikan agar tidak terjadi kerusakan yang serius.

Dua buah metode pengambilan keputusan dipilih untuk membuat perangkingan yaitu metode SAW dan metode AHP. Hasil eksperimen menunjukan bahwa hasil perangkingan menggunakan SAW dalam menentukan prioritas perbaikan fasilitas dirumah susun lebih baik dari pada hasil perangkingan menggunakan metode SAW. Selain itu penggunaan metode SAW juga lebih efisien karena kompleksitas dalam penentuan rangking lebih singkat dibandingkan menggunakan metode AHP.

\section{REFERENSI}

[1] Frieyadie, "PENERAPAN METODE SIMPLE ADDITIVE WEIGHT (SAW) DALAM SISTEM PENDUKUNG KEPUTUSAN PROMOSI KENAIKAN JABATAN," J. Pilar Nusa Mandiri, vol. 12, no. 1, pp. 3745, 2016, [Online]. Available https://media.neliti.com/media/publications/227474-penerapan-metodesimple-additive-weight-4b140887.pdf.

[2] F. Sonata, "Implementasi Metode Simple Additive Weighting (Saw) dengan Proses Fuzzifikasi dalam Penilaian Kinerja Dosen," J. Teknol. Inf. dan Komun., vol. 5, no. 2, pp. 71-80, 2016.

[3] T. B. Sunardi and D. Kriestanto, "Perbandingan AHP dan SAW Untuk Pemilihan Pegawai Terbaik (Studi Kasus: STMIK AKAKOM Yogyakarta)," Semin. Ris. Teknol. Inf., p. 9, 2016.

[4] M. Masri, "Penentuan Karyawan Terbaik Dengan Metode Simple Additive Weighting (PDAM Tirta Silaupiasa)," JET (Journal Electr Technol., vol. 1, no. 1, pp. 36-41, 2016, [Online]. Available: https://jurnal.uisu.ac.id/index.php/jet/article/view/187.

[5] E. Ismanto and N. Effendi, "Sistem Pendukung Keputusan Penerimaan Karyawan Dengan Metode Simple Additive Weighting (SAW)," SATIN - Sains dan Teknol. Inf., vol. 3, no. 1, p. 1, 2017, doi: 10.33372/stn.v3i1.208.

[6] A. Munthafa and H. Mubarok, "Penerapan Metode Analytical Hierarchy
Process Dalam Sistem Pendukung Keputusan Penentuan Mahasiswa Berprestasi," J. Siliwangi, vol. 3, no. 2, pp. 192-201, 2017.

[7] H. Situmorang, "Sistem Pendukung Keputusan Pemilihan Calon Peserta Olimpiade Sains Tingkat Kabupaten Langkat Pada Madrasah Aliyah Negeri ( Man ) 2 Tanjung Pura Denganmenggunakan Metode Simple Additive Weighting ( Saw ),” J. TIMES, vol. IV, no. 2, pp. 24-30, 2015.

[8] R. Umar, A. Fadlil, and Y. Yuminah, "Sistem Pendukung Keputusan dengan Metode AHP untuk Penilaian Kompetensi Soft Skill Karyawan," Khazanah Inform. J. Ilmu Komput. dan Inform., vol. 4, no. 1, p. 27, 2018, doi: $10.23917 /$ khif.v4i1.5978.

[9] F. Sholikhah, D. H. Satyareni, and C. S. Anugerah, "Perancangan Sistem Pendukung Keputusan Pemilihan Pelanggan Terbaik Menggunakan Metode Simple Additive Weighting (SAW) Pada Bravo Supermarket Jombang," Regist. J. Ilm. Teknol. Sist. Inf., vol. 2, no. 1, p. 40, 2016, doi: 10.26594/r.v2i1.444.

[10] L. A. Prasetyo, "Sistem Pendukung Keputusan Mahasiswa Berprestasi Menggunakan Metode Kombinasi Analytical Hierarchy Process (AHP) dan Simple Additive Weigting (SAW)," STRING (Satuan Tulisan Ris. dan Inov. Teknol., vol. 3, no. 2, p. 130, 2018, doi: 10.30998/string.v3i2.3039.

[11] D. R. Sari, A. P. Windarto, D. Hartama, and S. Solikhun, "Decision Support System for Thesis Graduation Recommendation Using AHPTOPSIS Method," J. Teknol. dan Sist. Komput., vol. 6, no. 1, pp. 1-6, 2018, doi: 10.14710/jtsiskom.6.1.2018.1-6.

[12] M. A. Sembiring, "Penerapan Metode Simple Additive Weighting Sebagai Strategi Pembinaan Kecerdasan Anak," Jurteksi, vol. 4, no. 1, pp. 65-70, 2017, doi: 10.33330/jurteksi.v4i1.35.

[13] S. A.M.Pebakirang, A. Sutrisno, and J. Neyland, "Penerapan Metode Ahp (Analytical Hierarchy Process ) Untuk Pemilihan Supplier Suku Cadang Di," J. Online Poros Tek. Mesin, vol. 6, no. 1, pp. 32-44, 2017.

[14] A. Setyawan, F. Y. Arini, and I. Akhlis, "Comparative Analysis of Simple Additive Weighting Method and Weighted Product Method to New Employee Recruitment Decision Support System (DSS) at PT. Warta Media Nusantara," Sci. J. Informatics, vol. 4, no. 1, pp. 34-42, 2017, doi: 10.15294/sji.v4i1.8458.

[15] N. Hasanah and R. Priambodo, "Perancangan Sistem Pendukung Keputusan Prioritas Program Kerja Dengan Metode Simple Additive Weighting ( Saw )," J. Cendikia, vol. 18, no. X, pp. 349-358, 2019.

[16] T. L. Saaty, "Decision making with the analytic hierarchy process," Int. J. Serv. Sci., vol. 1, pp. 83-98, 2008, doi: 10.1016/0305-0483(87)900168.

[17] T. Herdi, A. Dores, and F. Masya, "SIMPLE ADDITIVE WEIGHTING IN SELECTION OF CITIES PERFORMANCE OF NON SMOKING AREA AND TOBACCO ADVERTISEMENTS , PROMOTIONS AND SPONSORS BAN," pp. 71-79, 2020.

[18] DIREKTORAT JENDERAL CIPTA KARYA, "Permen PU nomor 24 tahun 2008 tentang Pedoman Pemeliharaan Gedung," p. 16, 2008. 